\title{
A study on the compressive strength and microstructure characteristic of alkali-activated metakaolin cement
}

\author{
Mehmet Karatas ${ }^{2}$, Murat Dener ${ }^{1}$, \\ Mehrzad Mohabbi ${ }^{1}$, Ahmet Benli ${ }^{1}$
}

\footnotetext{
${ }^{1}$ Department of Civil Engineering, Bingol University, Bingol, Eastern Anatolia, Turkey.

e-mail: ahbenli@gmail.com, abenli@bingol.edu.tr, mdener@bingol.edu.tr, mmohabbi@bingol.edu.tr

${ }^{2}$ Department of Civil Engineering, Firat University, Elazig, Eastern Anatolia, Turkey.

e-mail: mkaratas@firat.edu.tr
}

\begin{abstract}
The main purpose of this study was to investigate the compressive strength and microstructure characteristic of alkali-activated metakaolin cement (AAMC). In accordance with this purpose, besides the pure metakaolin activation five other mixtures were designed by substitution of different OPC ratios instead of metakaolin (MK) from 0 to $25(5,10,15,20,25 \%$ OPC). AAMC was activated with sodium silicate (Na2SiO3) of modulus $\mathrm{Ms}=\mathrm{SiO}_{2} / \mathrm{Na} 2 \mathrm{O}=3.1$ and $\mathrm{NaOH}$ solutions $(32 \%$ of $\mathrm{NaOH}, 68 \%$ of water by mass). The ratio of liquid/solid (L/S) was kept constant at 0.65 . All specimens were cured at $70{ }^{\circ} \mathrm{C}$ for 72 hours then kept in room conditions until the days that experiments were performed. Compressive strength and UPV experiment tests were carried out on all specimens at different curing periods of 3,14,28 and 90 days. In addition, the microstructure of 28 days alkali-activated metakaolin cements were analyzed with scanning electron microscope (SEM). The results showed that AAMC specimens reached the desired strength and major part of the final strength was gained at the end of 3 days of curing.
\end{abstract}

Keywords: Alkali activated cement; Geopolymer; Metakaolin, microstructure, UPV

\section{INTRODUCTION}

Alkali activated cements are inorganic polymers generated from activation of solid aluminosilicate materials such as blast furnace slag, fly ash or metakaolin to form a new class of three-dimensionally network of alkali alumino-silicate[1-3]. Studies on the improvement of alkali activated binder as an alternative to conventional cement has been considerably increased in the last years. The reasons of this increase are many advantages of alkali activated cements over conventional cement such as lower $\mathrm{CO} 2$ emission and development of desired strength and structural properties [4]. The use of high cement content in the construction sector is neither economically nor environmentally acceptable. It is known that about $7 \%$ of global $\mathrm{CO} 2$ emissions originate from Portland cement production. The decrease of Portland cement production percentage will reduce the degradation of raw materials and also reduce the rate of $\mathrm{CO} 2$ released to the atmosphere which will affect the hazard of global warming [5,6]. Supplementary materials such as fly ash, ground granulated blast furnace slag, silica fume, and metakaolin are used as partial replacements to decrease the consumption of Portland cement [3,5]. Nevertheless when these supplementary materials are used more than a certain amount the mechanical properties of the cement are greatly reduced, particularly at early ages [7]. Alkaline-activated cements and/or geopolymers which are investigated in our study can produce up to $100 \%$ of replacement of these materials with Portland cement.

Metakaolin is the low-calcium material one of the most commonly used in alkaline cement. The main reaction product of activation of materials such as kaolin comprising primarily aluminum and silicon is $\mathrm{N}-\mathrm{A}$ -S-H (geopolymer) gel which is three dimensional inorganic alkaline polymers [8]. Fernandez-Jiménez et al. explain $\mathrm{N}-\mathrm{A}-\mathrm{S}-\mathrm{H}$ gel formation as follows. When the aluminosilicate source is contacted with the alkali solution, it is dissolved in many species, primarily silica and alumina monomers. Dimers are formed by these monomers interaction then interact with the monomers to form the trimers, tetramers and so on [9].

Very few research has been done on AAMC[10]. Rashad et al.[11] studied compressive strength of 
alkali-activated metakaolin replaced with quartz powder at different levels ranging from 0 to $30 \%$ with an increment of $5 \%$, by weight. They reported that the mixture produced from fully metakaolin exhibited high compressive strength at age of seven days. They also reported that 28 and 365 days compressive strength was only $2.22 \%$ and $3.4 \%$ higher, respectively, in comparison with 7 days. In a study conducted by Wianglor et al. [10] OPC was used to replace part of metakaolin at 5, 10, 15, 20, 30\% by mass of binder.

Specimens were cured at $23 \pm 2^{\circ} \mathrm{C}(55 \% \mathrm{RH})$ and $60^{\circ} \mathrm{C}(95 \% \mathrm{RH})$ conditions. With the increase of $\mathrm{OPC}$ replacement and curing temperature compressive strength of AAMC increased. At $60^{\circ} \mathrm{C}(95 \% \mathrm{RH})$ curing condition matrices appeared denser than when cured at $23 \pm 2{ }^{\circ} \mathrm{C}(55 \% \mathrm{RH})$. Yunsheng et al. [12] studied effect of slag replacement on the mechanical properties of MK/slag alkali activated mortars. Water/binder ratios were kept constant as 0.35 for all mixtures. The all specimens were cured at $20^{\circ} \mathrm{C}$ and $100 \%$ relative humidity for 28 days. Replacement of slag increased both compressive and flexural strength.

The highest compressive and flexural strengths were obtained in the mixture containing $50 \%$ slag and they are 64.1 $\mathrm{MPa}$ and 8.01 $\mathrm{MPa}$, respectively. Buchwald et al.[13] studied the performance of Alkaliactivated metakaolin-slag blends. They used $\mathrm{NaOH}$ as alkali activator. It is reported that the blend containing $100 \%$ slag reached the highest strength values while blend containing $100 \%$ metakaolin showed a lowest strength. The blends containing metakaolin/slag $(0.5 / 0.5)$ and $(0.25 / 0.75)$ reached similar strength values. Burciaga-Diaz and Escalante-Garcia [14] compared the performance of alkali activated slag/metakaolin cement pastes. They prepared mixes of slag-metakaolin weight proportions of 100-0, 50-50 and 0-100. They also prepared a blended ordinary Portland cement as control. The alkaline activators used composed of blends of sodium silicate. Different water/solid ratios were used in each mix. They kept all specimens at $20 \mathrm{C}$ and $80 \%$ relative humidity for $24 \mathrm{~h}$ then at $60 \mathrm{C}$ in dry conditions for $48 \mathrm{~h}$. The one with $100 \% \mathrm{BFS}$ reached the highest strength of $92 \mathrm{MPa}$. The mixtures 50-50, \%100 MK, and the control reached 58, 41 and $53 \mathrm{MPa}$ respectively. There are some other studies on kaolin based alkali activated materials [15-17].

The main objective of this study is to explore the compressive strength of alkali-activated metakaolin cement (AAMC) by destructive and non-destructive methods and also the microstructure was assessed using SEM and EDX. For this objective, six mixtures were used, which were substituted MK with OPC and a mixture was used as a control. Strength properties were assessed by compressive strength and UPV measurement at 3,14, 28, and 90 days. Water absorption of AAMC specimens were tested at 28 days of curing period for durability property.

\section{MATERIALS AND METHODS}

\subsection{Aluminosilicate precursors}

The raw material (precursors) used in the study was metakaolin (MK). Particle size distributions $\mathrm{d}_{50}, \mathrm{~d}_{90}$ and $\mathrm{d}_{98}$ were $4.22 \mu \mathrm{m}, 21.43 \mu \mathrm{m}$ and $37.84 \mu \mathrm{m}$ respectively. Chemical composition of metakaolin precursor is shown in Table 1.

Table 1: Chemical composition of Metakaolin

\begin{tabular}{lc}
\hline Chemical composition (\%) & $\mathrm{MK}$ \\
\hline $\mathrm{SiO}_{2}$ & 50.62 \\
$\mathrm{Al}_{2} \mathrm{O}_{3}$ & 45.7 \\
$\mathrm{Fe}_{2} \mathrm{O}_{3}$ & 0.31 \\
$\mathrm{CaO}$ & 0.2 \\
$\mathrm{MgO}$ & 0.32 \\
$\mathrm{Na}_{2} \mathrm{O}+\mathrm{K}_{2} \mathrm{O}$ & 0.32 \\
$\mathrm{Na}_{2} \mathrm{O}+0.658 \mathrm{~K}_{2} \mathrm{O}$ & - \\
\hline
\end{tabular}

\subsection{Portland Cement}

An ordinary Portland cement (CEM I 42.5N) was used to replace metakaolin at different rates. Chemical and physical properties of Portland cement are shown in Table 2. 
Table 2: Properties of Portland cement

\begin{tabular}{lc}
\hline Chemical composition (\%) & OPC \\
\hline $\mathrm{SiO}_{2}$ & 21.12 \\
$\mathrm{Al}_{2} \mathrm{O}_{3}$ & 5.62 \\
$\mathrm{Fe}_{2} \mathrm{O}_{3}$ & 3.24 \\
$\mathrm{CaO}$ & 62.94 \\
$\mathrm{SO}_{3}$ & 2.3 \\
Loss in ignition & 3.52 \\
Physical Properties & \\
Specific Gravity $\left(\mathrm{g} / \mathrm{cm}^{3}\right)$ & 3.1 \\
Specific Surface Area $\left(\mathrm{cm}^{2} / \mathrm{g}\right)$ & 3490 \\
\hline
\end{tabular}

\subsection{Alkali activators}

A mixture of sodium hydroxide solution and sodium silicate solution was used to activate aluminosilicate precursor. Sodium silicate $\left(\mathrm{Na}_{2} \mathrm{SiO}_{3}\right)$ solution used in this study is commercially available. The ratio of $\mathrm{SiO}_{2}$ to $\mathrm{Na}_{2} \mathrm{O}$ by mass(Ms) in the sodium silicate solution was 3.1. Chemical composition of sodium hydroxide solution used is $\mathrm{NaOH}-32 \%$, Water $-68 \%$ by mass. Alkali activators were used as $65 \%$ by weight of the total binder.

\subsection{Superplasticizer}

Modified polycarboxylate-based polymer type superplasticizer (SP) was used in this study. The specific weight of SP used was about $1.1 \mathrm{~g} / \mathrm{cm}^{3}$ and $\mathrm{pH}$ was in the range of 3-7. SP was used as two percent by weight of the total binder.

\subsection{Preparation of mixtures and experimental techniques}

To investigate the compressive strength and microstructure characteristic, six mixtures were designed in this study which is shown in Table 3. The ratio of liquid/solid (L/S) and superplasticizer percentage of all mixtures were kept constant to compare the compressive strengths to each other. In our study, liquid refers total alkali solution and solid refers total binder. All pastes were blended with the aid of a mixer for about three minutes. After mixing pastes were cast into 50*50*50 $\mathrm{mm}^{3}$ cubic molds and vibrated for one min. with the vibrating table. Molds were completely covered with film made of polyethylene[1]. After these steps, all mixtures were cured at $70{ }^{\circ} \mathrm{C}$ in an oven for $72 \mathrm{~h}$. After $72 \mathrm{~h}$ cured at $70{ }^{\circ} \mathrm{C}$, the specimens were demoulded and kept in room temperature for different curing periods. Ultrasonic Pulse Velocity(UPV) measurements and compressive strength experiments were performed after 3, 14, 28 and 90 days of curing periods of all specimens. Also the microstructure properties were observed using scanning electron microscopy(SEM).

Table 3: Mix proportions

\begin{tabular}{|c|c|c|c|c|c|c|}
\hline \multirow{2}{*}{ Formulation } & \multicolumn{2}{|c|}{ Replacement(wt\%) } & \multirow[t]{2}{*}{ Ms } & \multirow[t]{2}{*}{$\mathrm{Na}_{2} \mathrm{SO}_{3} / \mathrm{NaOH}$ (byweight) } & \multirow[t]{2}{*}{$\mathrm{L} / \mathrm{S}$} & \multirow[t]{2}{*}{$\mathrm{SP}(\%)$} \\
\hline & MK & $\mathrm{PC}$ & & & & \\
\hline MK & 100 & - & 3.1 & 3 & 0.65 & 2 \\
\hline MKC05 & 95 & 5 & 3.1 & 3 & 0.65 & 2 \\
\hline MKC10 & 90 & 10 & 3.1 & 3 & 0.65 & 2 \\
\hline MKC15 & 85 & 15 & 3.1 & 3 & 0.65 & 2 \\
\hline MKC20 & 80 & 20 & 3.1 & 3 & 0.65 & 2 \\
\hline MKC25 & 75 & 25 & 3.1 & 3 & 0.65 & 2 \\
\hline
\end{tabular}




\subsection{Compressive strength test}

Compressive strength test were carried out according to ASTM C 39[2]. The average of three specimens was used at these experiments. Compressive strength was determined at the age of 3, 14, 28 and 90 days for aging effect of AAMC.

\subsection{Ultrasonic pulse velocity test (UPV)}

The UPV measurements, a non-destructive test to learn the quality of concrete in terms of velocity, was carried out according to ASTM C597[3]. UPV measurements were conducted on cube samples of 50x50x50 $\mathrm{mm}^{3}$ at different days of curing. A relationship is established between the UPV values and the compressive strength of the concrete. There is no direct relationship between the UPV values and the compressive strength but there is a certain relationship between the UPV values and the density of the concrete i.e. the higher UPV value the higher density. And the higher density means higher compressive strength[4].

\subsection{Water absorption tests}

Water absorption were performed on the specimens according to ASTM C642[5] end of 28 days of curing period. The weight of saturated and oven-dried specimens was measured to determine the water absorption value. The measured values were calculated using Eqs. (1) The results were obtained by the average of three samples. Methods for measuring water absorption were used successfully in a number of studies $[6,7]$.

$$
\operatorname{Absorbtion}(\%)=\frac{W_{a}-W_{d}}{W_{d}} * 100
$$

Where absorption is water absorption of AAMC paste $(\%), \mathrm{W}_{\mathrm{a}}$ is weight in air of saturated specimens $(\mathrm{g})$ and $\mathrm{W}_{\mathrm{d}}$ is weight of dried specimen $(\mathrm{g})$.

\section{RESULTS AND DISCUSSION}

\subsection{Compressive strength results}

Fig. 1 shows 3, 14, 28 and 90 days of compressive strengths results of alkali-activated metakaolin cement pastes. As can be seen, significant increases in compressive strength were observed with the replacement of OPC with metakaolin at different ratios. This increase has begun with the replacement of OPC with $5 \%$ metakaolin which is the lowest rate of replacement. At the end of 28 days, the increases in the compressive strength of the MKC05, MKC10, MKC15, MKC20, MKC25 mixtures compared to the mixture produced entirely of metakaolin was $33.3,38.5,41.2,47.9,54 \%$ respectively. The compressive strength gaining were higher at the end of the third day compared to day of 28 . When the compressive strengths of blends containing OPC and blend produced with entirely kaolin are compared it is seen that the difference between the compressive strengths is generally reduced with the increase of the curing period. Compressive strength gaining are based on formation of $\mathrm{C}-\mathrm{S}-\mathrm{H}$ gels resulting from OPC hydration, besides formation of $\mathrm{N}-\mathrm{A}-\mathrm{S}-\mathrm{H}$ $\left(\mathrm{Na}_{2} \mathrm{O}-\mathrm{Al}_{2} \mathrm{O} 3-\mathrm{SiO}_{2}-\mathrm{H}_{2} \mathrm{O}\right)$ gels resulting from geopolymerization [8].

A research conducted by Garcia-Lodeiro has revealed that these two products don't develop singularly as two separate gels, they interact so structural and compositional change occurs in the process[9]. The compressive strength of all mixtures increased with the curing period. Compressive strengths of MK mixture at 14, 28 and 90 days were 4.9, 15.6 and 16.6 higher compared to day of 3, respectively. Compared to third day, compressive strength of MKC25 mixture at 14, 28 and 90 days were 9.2, 10.8 and 11.4\% higher, respectively. Rate of compressive strength increases of mixtures containing OPC were similar to each other. When it comes to the difference between the initial and final compressive strengths of all mixtures, the compressive strength for MK, MKC05, MKC10, MKC15, MKC20 and MKC25 mixtures increased 16.6, 11.6, 6.9, 8.9, 11.7 and $11.4 \%$, respectively. 


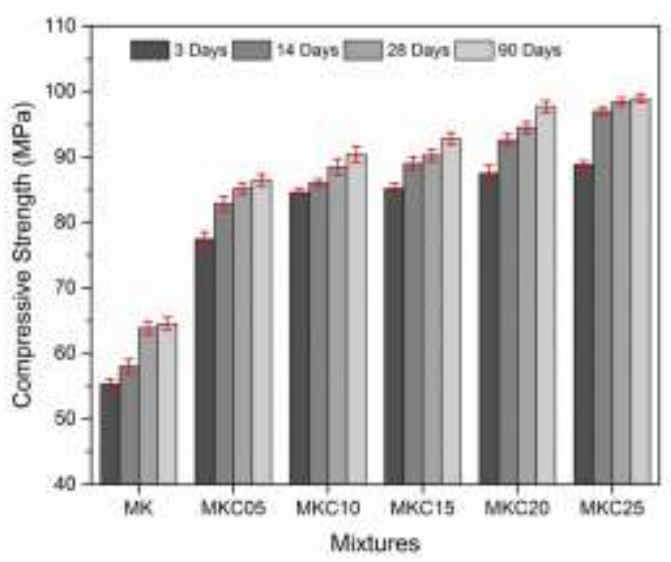

Figure 1: Compressive strength of AACM specimens at different ages.

In Fig. 1, when compared to final strength that AAMC specimens gained it is seen that the compressive strength of the samples obtained from all the mixtures on the 3rd day is very significant. The blend which is completely produced with kaolin has already achieved $83 \%$ of its final strength at the end of 3 days curing period. It can be seen how high the early age compressive strength of alkali activated metakaolin based cements are when compared to the strength of normal concretes obtained in 3 days. In a study conducted by Wang [10] on compressive strength development of cement mortar it is reported that the 3 day compressive strength of normal concrete produced entirely from Portland cement is $58.9 \%$ of the 90 day compressive strength. In another study[11] metakaolin is used as mineral additive the result show that the 3 day compressive strength is about $40 \%$ of the 28 day compressive strength. In these types of cements produced by the activation of metakaolin with alkali activators the 3 day strength of the MK mixture was $86.4 \%$ of the 28 day strength. The compressive strength results show that these AAMC pastes produced at these mixing ratios achieved relatively high early strength as well as the desired final strength. Fig. 2 shows the specimens from all blends subjected to the compressive strength and other experiments. As OPC replacement increased the color of specimens changed from cream to gray. The fact that the specimens have a smooth surface indicates good workability when fresh.

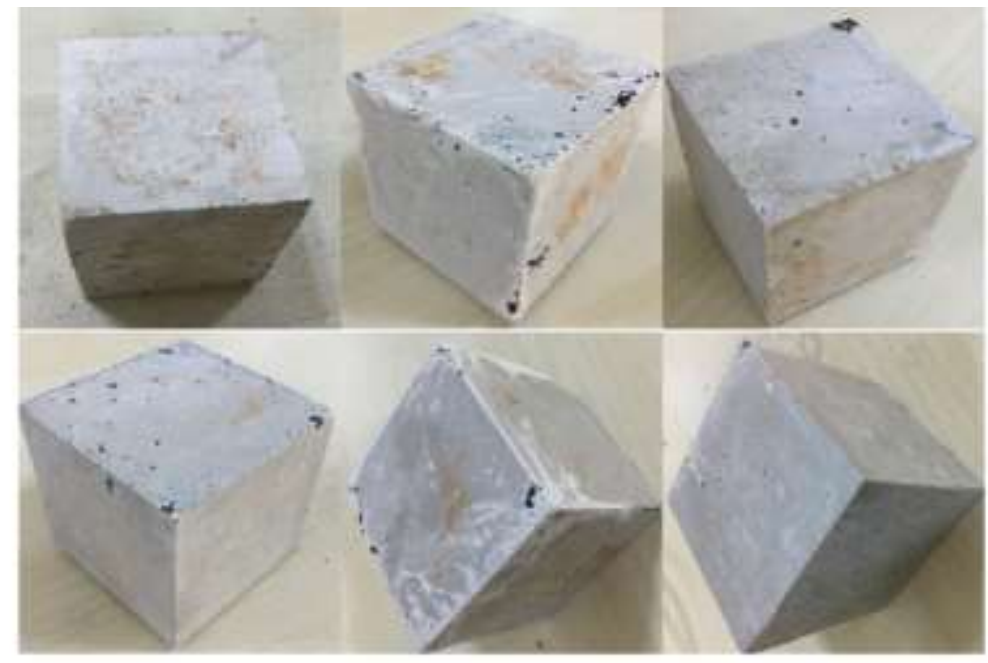

Figure 2: Hardened MK, MKC05, MKC10, MKC15, MKC20, MKC25 specimens, respectively 


\subsection{UPV results}

UPV results of AAMC specimens are shown in Fig. 3. The results of the UPV, a non-destructive test method, supported the compressive strength results. At the end of the 28-day curing period, UPV values were measured as 2956, 3247, 3356, 3356, 3472 and 3472 (m/s) for MK, MKC05, MKC10, MKC15, MKC20 and MKC25 specimens, respectively. It is seen that UPV values tend to increase as OPC content increase. these increase rates are more evident at age of 90. The UPV value measured at the end of 3 days of curing time of the specimens containing $100 \%$ metakaolin was $2874(\mathrm{~m} / \mathrm{s})$ whereas this value was $3056(\mathrm{~m} / \mathrm{s})$ after 90 days of curing period increasing $6 \%$. The difference between the 3 and 90 days of curing period of the MKC05, MKC10, MKC15, MKC20 and MKC25 mixtures were 6.9, 9.3, 4.4, 4.9 and 2.9\%, respectively. Although UPV values increase with the cement content and aging there are cases where the UPV values remain constant in two consecutive cement contents or two different curing periods. Then it can be said that UPV values increases with aging and OPC content but this increases were not as evident as the increase in compressive strength.

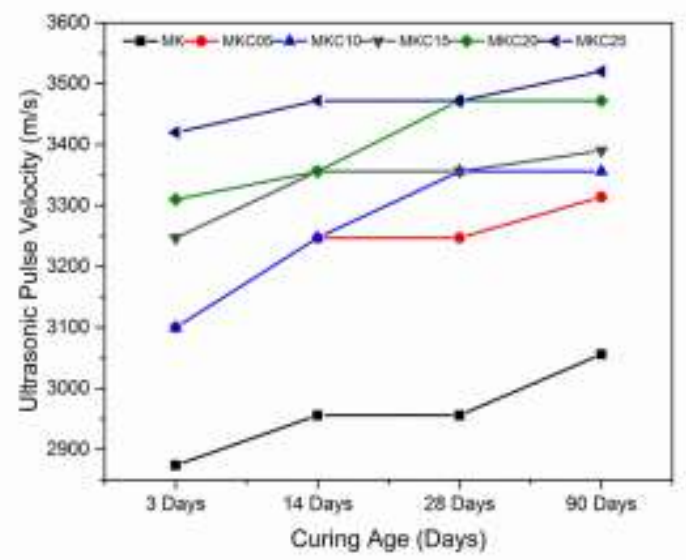

Figure 3: UPV results of AACM specimens at different ages

The ultrasonic device is used to measure the transit time of ultrasonic waves sent to specimen from one surface to another and so the wave velocity is calculated. The relationship between the calculated supersonic wave velocity and the compressive strength of the AAMC specimen is approximately obtained[4]. Fig. 4 shows the relationship between compressive strength and UPV results at the end of 28 days of curing. As mentioned earlier, there was a high relationship between pressure resistance and UPV results. Coefficient of determination $\left(\mathrm{R}^{2}\right)$ was 0.9721 . This means that we can estimate the compressive strength over the UPV results by $97.21 \%$ ? Coefficient of determination $\left(\mathrm{R}^{2}\right)$ proved strong relationship between these two variables.

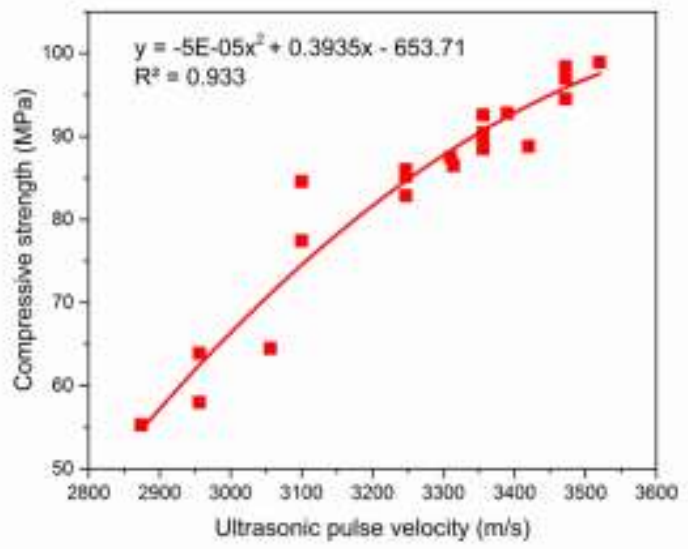

Figure 4: Relationship between the compressive strength and UPV at the age of 28 


\subsection{Water absorption}

Figure 5 shows the water absorption and compressive strength of the specimens taken from all mixtures at the end of the 28 days of curing period. The water absorption percentages of the samples obtained from the mixtures of MK, MKC 05, MKC 10, MKC 15, MKC 20 and MKC 25 were 21.51, 17.52, 17.73, 16.82, 13.17 , and $12.53 \%$, respectively. It is evident that the water absorption reduces with increasing in OPC content in all specimens. Hydration and C-A-S-H increases with increasing OPC content. The new products fill the pores and thus reduce water absorptions with corresponding increase in compressive strengths[7]. Although the rate of water absorption decreased as the amount of OPC added increased, the water absorption values were high due to the fact that the metakaolin used was very fine grained. Similar values for water absorption in alkali active cements were obtained in other studies [6,7].
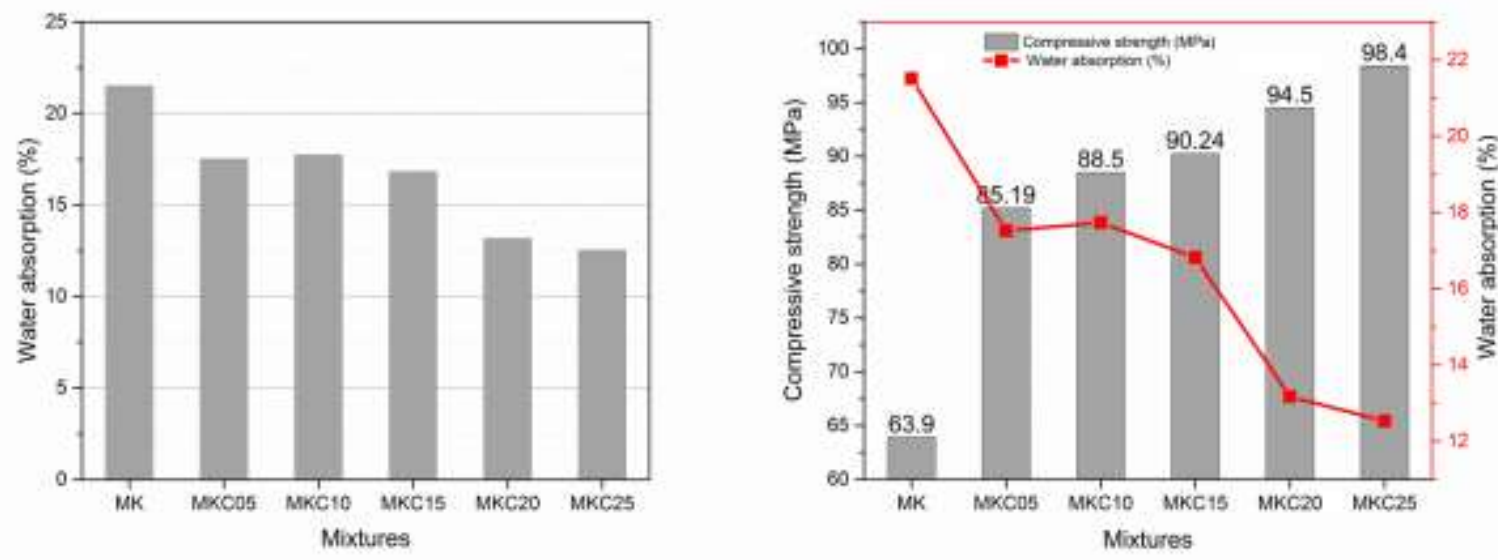

Figure 5: Water absorption and compressive strength of AAMC specimens at the age of 28

As shown in Fig. 6, there is a close relationship between water absorption and compressive strength of AAMC specimens. High water absorption capacity has lower strength. The strong correlation between these two variables was supported by the coefficient determination( $R$ squared). Ax $2+b x+c$ is the polynomial equation that best matches the $\mathrm{R} 2$ values for these variables. This $\mathrm{R}^{2}$ value is 0.9774 . That means the compressive strengths can be predicted by water absorption percentage by $97,74 \%$ accuration.

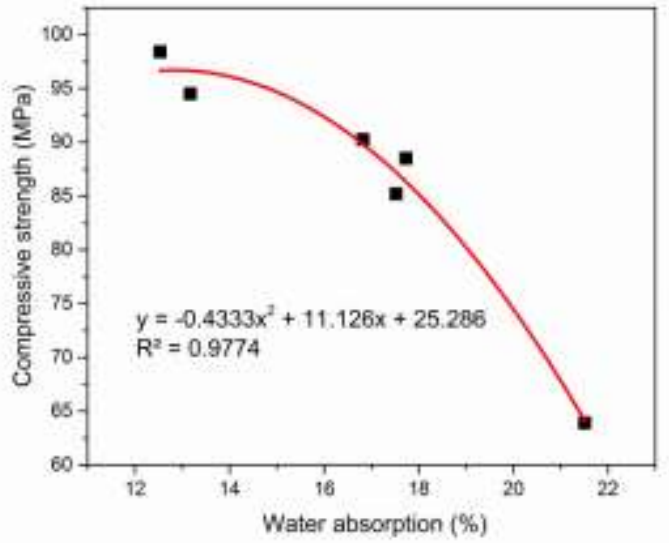

Figure 6: Relationship between the compressive strength and water absorption at the age of 28 


\subsection{SEM analyses}

SEM image and EDX results of AAC specimens are shown in Figures 7-10. The main reaction product formed from activation of metakaolin is $\mathrm{Na}_{2} \mathrm{O}-\mathrm{Al}_{2} \mathrm{O}_{3}-\mathrm{SiO}_{2}-\mathrm{H}_{2} \mathrm{O}(\mathrm{N}-\mathrm{A}-\mathrm{S}-\mathrm{H})$ geopolymer gel which can be regarded as a zeolite precursor [8]. In Fig. 7, specimen having 100\% metakaolin, it can be seen that N-A-S-H gel have formed. Elemental compositions obtained from EDX results confirm that these have occurred. The reaction products forming during of alkaline activation of OPC and low $\mathrm{CaO}$ contents materials(such as metakaolin or type $\mathrm{F}$ fly ash) are $\mathrm{N}-\mathrm{A}-\mathrm{S}-\mathrm{H}$ and $\mathrm{C}-\mathrm{S}-\mathrm{H}[8]$. A research has evinced that these two products don't evolve as two separate gels. There are composition and structural change through interaction of between these gels[9]. As can be seen from EDX results in Figures 7-10, Ca increased as OPC replacement increased. The increase in calcium demonstrates the co-existence of $\mathrm{N}-\mathrm{A}-\mathrm{S}-\mathrm{H}$ and $\mathrm{C}-\mathrm{S}-\mathrm{H}$ gels. We can see from paste SEM images with OPC increase in our mixes they seem more condensed. In cement hydration process at aqueous state mainly involve of $\mathrm{C}_{3} \mathrm{~S}, \mathrm{C}_{2} \mathrm{~S}, \mathrm{C}_{3} \mathrm{~A}$, and $\mathrm{C} 4 \mathrm{AF}$ also clinker sulfate and gypsum. In the hydration process, $\mathrm{C}_{3} \mathrm{~A}, \mathrm{C}_{4} \mathrm{AF}, \mathrm{C}_{3} \mathrm{~S}$, and $\mathrm{C}_{2} \mathrm{~S}$ will carry out a complex hydration reaction to form ettringite, calcium hydroxide, and $\mathrm{C}-\mathrm{S}-\mathrm{H}$ gel. The Hydration of tricalcium aluminate will form ettringite. The reactions has been shown in below:

\section{$\mathrm{C}_{3} \mathrm{~A}+32 \mathrm{H}+3 \mathrm{CaSO} 4 \rightarrow \mathrm{C}_{3} \mathrm{~A} \cdot 3 \mathrm{CSH}_{32} \rightarrow \mathrm{C}_{6} \mathrm{AS}_{3} \mathrm{H}_{32}$ \\ C6AS3H32 $=($ Calcium Aluminate Tri Sulphate Hydrate or Ettringite $)$}

The reaction of pure $\mathrm{C}_{3} \mathrm{~A}$ with water is very fast and this may lead to prohibition from flash setting gypsum is added for cement. Needle shape jel prepared a new type amorf materials that have been obviously seen in figures C,D,E also Unreacted or partially reacted OPC particles have not seen in the matrixes. The geopolymer gels produced by the dissolution of metakaolin generally have insignificant amount of calcium, which is primarily sodium alumino-silicate hydrate (N-A-S-H). In shape (a) we can see only N-A-S-H gels with partially cement hydration product. In the mix samples of this research, presence of calcium in the geopolymeric gel is confirmed as shown in typical EDX diagrams shown in Figures7-10. Inclusion of ordinary Portland cement supplies additional calcium and thus contributes to formation of the binding product containing calcium ion. these new combined matrixes are more strength i.e. the more $\mathrm{Ca}$ ions the more strength .in other words our hypothesis these two materials don't evolve as two separate gels and Composition and structural change have been occurred from interaction of gels has been proved.
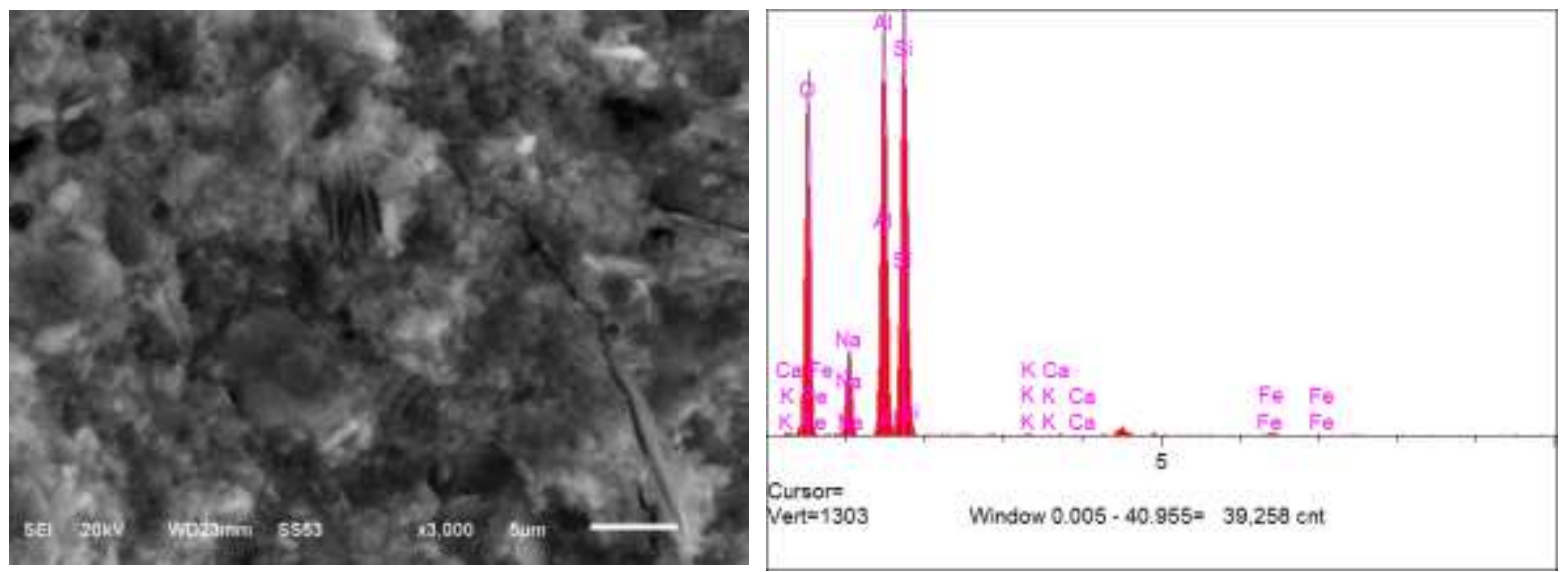

Figure 7: SEM micrographs for MK at the age of 28 


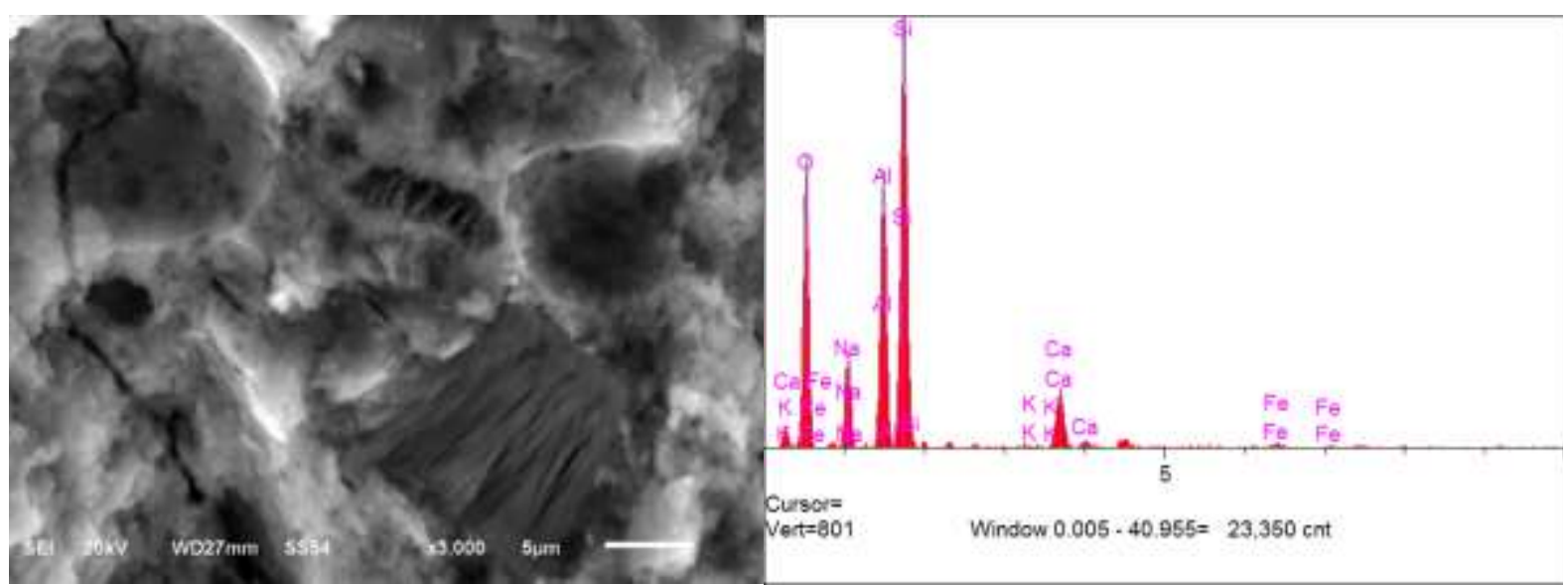

Figure 8: SEM micrographs for MKC05 at the age of 28

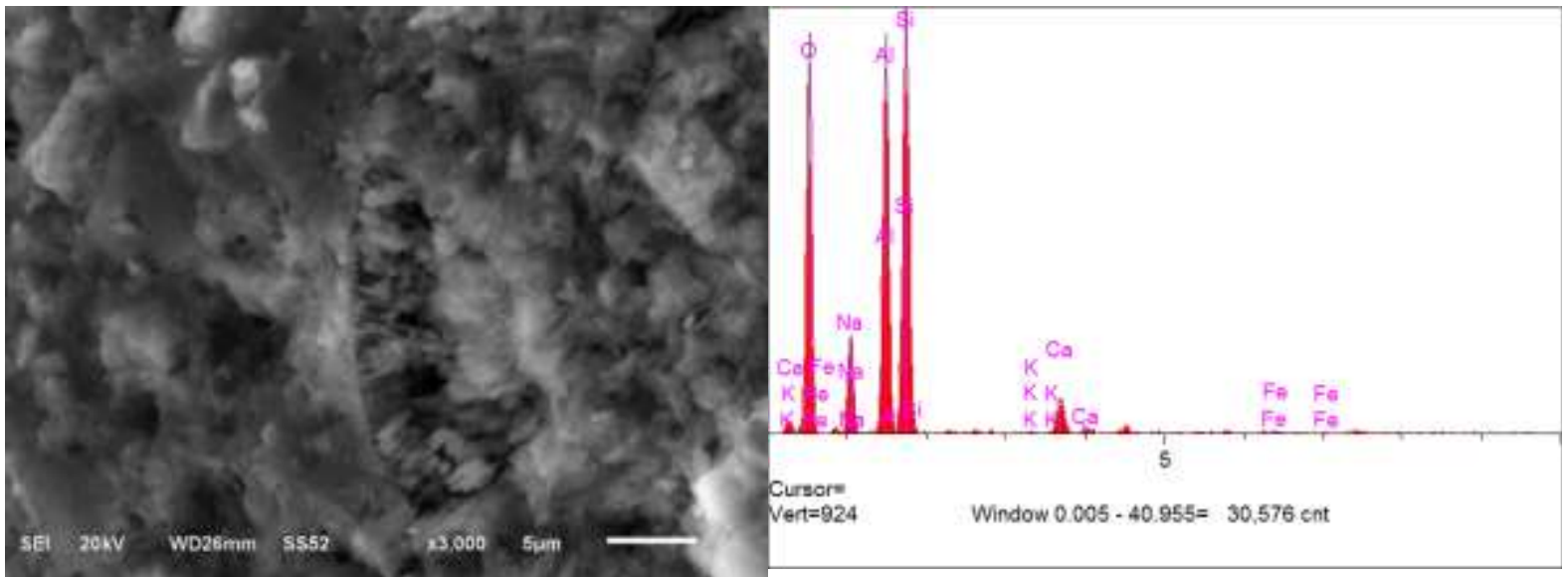

Figure 9: SEM micrographs for MKC10 at the age of 28
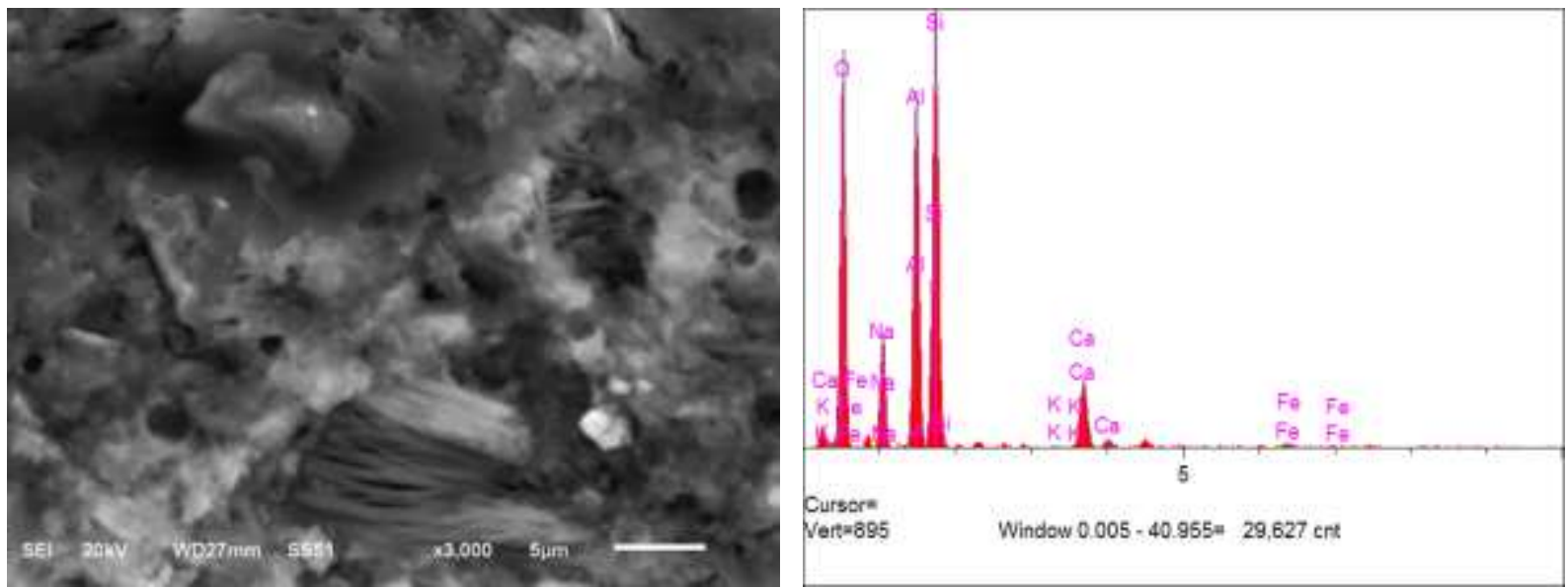

Figure 10: SEM micrographs for MKC20 at the age of 28 


\section{CONCLUSIONS}

The main purpose of this study was to investigate the compressive strength of alkali activated metakaolin based cements activated with mixture of $\mathrm{NaOH}$ and $\mathrm{Na}_{2} \mathrm{SiO}_{3}$ solutions at the ratio of 1:3. Significant increases in compressive strength were observed with the replacement of OPC. At the end of the 28 days in 5\% OPC substitution which is the lowest percentage of replacement, compressive strength was 1.33 times higher than mixtures produced with fully metakaolin. This value was 47.9 for $25 \%$ OPC substitution.

When investigating effect of strength gaining it is seen that a significant part of the final strength is gained at the end of 3 days of curing period. these final strength gaining rates are 16.6, 11.6, 6.9, 8.9, 11.7 and $11.4 \%$ for MK, MKC05, MKC10, MKC15, MKC20 and MKC25, respectively. During the 90 day of curing period none of the compressive strength of the specimens decreased with aging. This type of cements can be used as building material because of reaching desired strength and not decreased the strength during the curing period. The water absorption of the MK samples were too high but with increasing percentage of OPC, water absorption decreased considerably. Increase in compressive strength of OPC containing mixtures compared to blends produced $100 \%$ kaolin is a result of formation of new gel structures.

\section{BIBLIOGRAPHY}

[1] SLATY, KHOURY, F. H., RAHIER, H., et al., "Durability of alkali activated cement produced from kaolinitic clay", Applied Clay Science, v. 104, pp. 229-237, Feb, 2015.

[2] PARVEEN, J., SINGHAL, D., "Development of mix design method for geopolymer concrete", Advances in Concrete Construction, v. 5, n. 4, pp. 377-390, Aug, 2017.

[3] JINDAL, B. B., SINGHAL, D., SHARMA ET AL.,S., "Enhancing mechanical and durability properties of geopolymer concrete with mineral admixture," Computers and Concrete, v. 21, n. 3, pp. 345-353, Mar, 2018.

[4] DEB, P. S., SARKER, P. K., BARBHUIYA, S., "Sorptivity and acid resistance of ambient-cured geopolymer mortars containing nano-silica", Cement \& Concrete Composites, v. 72, pp. 235-245, Sep, 2016.

[5] SUMESH, M., ALENGARAM, U. J., JUMAAT, M. Z., et al., "Incorporation of nano-materials in cement composite and geopolymer based paste and mortar - A review", Construction and Building Materials, v. 148, pp. 62-84, Sep 1, 2017.

[6] ALIABDO, A. A. A., ABD ELMOATY, M., SALEM, H. A., "Effect of cement addition, solution resting time and curing characteristics on fly ash based geopolymer concrete performance", Construction and Building Materials, v. 123, pp. 581-593, Oct 1, 2016.

[7] ANGULO-RAMIREZ, D. E., GUTIERREZ, R. M., PUERTAS, F., "Alkali-activated Portland blastfurnace slag cement: Mechanical properties and hydration", Construction and Building Materials, v. 140, pp. 119-128, Jun 1, 2017.

[8] PALOMO, A., KRIVENKO, P., GARCIA-LODEIRO ET AL., I., "A review on alkaline activation: new analytical perspectives", Materiales De Construccion, v. 64, n. 315, 2014.

[9] FERNANDEZ-JIMENEZ, A., PALOMO, A., "Composition and microstructure of alkali activated fly ash binder: Effect of the activator", Cement and Concrete Research, v. 35, n. 10, pp. 1984-1992, Oct, 2005.

[10] WIANGLOR, K., SINTHUPINYO,S., PIYAWORAPAIBOON ET AL., M., "Effect of alkali-activated metakaolin cement on compressive strength of mortars", Applied Clay Science, v. 141, pp. 272-279, Jun, 2017.

[11] RASHAD, A. M., HASSAN, A. A., ZEEDAN, S. R., "An investigation on alkali-activated Egyptian metakaolin pastes blended with quartz powder subjected to elevated temperatures", Applied Clay Science, v. 132, pp. 366-376, Nov, 2016.

[12] ZHANG, Y. S., SUN, W., CHEN ET AL., Q. L., "Synthesis and heavy metal immobilization behaviors of slag based geopolymer", Journal of Hazardous Materials, v. 143, n. 1-2, pp. 206-213, May 8, 2007.

[13] BUCHWALD, A., HILBIG, H., KAPS, C., "Alkali-activated metakaolin-slag blends - performance and structure in dependence of their composition", Journal of Materials Science, v. 42, n. 9, pp. 3024-3032, May, 2007.

[14] BURCIAGA-DIAZ, O., ESCALANTE-GARCIA, J. I., "Comparative performance of alkali activated slag/metakaolin cement pastes exposed to high temperatures", Cement \& Concrete Composites, v. 84, pp. 157-166, Nov, 2017. 
[15] OK OYE, F. N., "Geopolymer binder: A veritable alternative to Portland cement," Materials TodayProceedings, v. 4, n. 4, pp. 5599-5604, 2017.

[16] OKOYE, F. N., DURGAPRASAD, J., SINGH, N. B., "Mechanical properties of alkali activated flyash/Kaolin based geopolymer concrete", Construction and Building Materials, v. 98, pp. 685-691, Nov 15, 2015.

[17] TCHAKOUTE, H. K., RUSCHER, C. H., "Mechanical and microstructural properties of metakaolinbased geopolymer cements from sodium waterglass and phosphoric acid solution as hardeners: A comparative study", Applied Clay Science, v. 140, pp. 81-87, May, 2017.

[18] YADOLLAHI,M. M., BENLI, A., DEMIRBOGA, R., "The effects of silica modulus and aging on compressive strength of pumice-based geopolymer composites", Construction and Building Materials, v. 94, pp. 767-774, Sep 30, 2015.

[19] ASTM, “ASTM C 39M-05”, Standard test method for compressive strength of cylindrical concrete specimens, ASTM International, West Conshohocken, PA, 2005.

[20] ASTM, “ASTM C597" Standard Test Method for Pulse Velocity Through Concrete, Am. Soc. Test. Mater. West Conshohocken, PA, USA. (2016) 1-4. , 2016.

[21] ERDOGAN, T., Concrete, Ankara, METU Publisher, 2003.

[22] ASTM, “ASTM C642 - 13”, Standard Test Method for Density, Absorption, and Voids in Hardened Concrete, 2013.

[23] THOKCHOM, S., GHOSH, P., GHOSH, S., "Effect of water absorption, porosity and sorptivity on durability of geopolymer mortars", ARPN Journal of engineering and Applied Sciences, v. 4, n. 7, pp. 28-32, 2009.

[24] PANGDAENG, S., PHOO-NGERNKHAM, T., SATA ET AL., V., "Influence of curing conditions on properties of high calcium fly ash geopolymer containing Portland cement as additive", Materials \& Design, v. 53, pp. 269-274, Jan, 2014.

[25] GARCIA-LODEIRO, I., PALOMO, A., FERNANDEZ-JIMENEZ., et al., A., "Compatibility studies between N-A-S-H and C-A-S-H gels. Study in the ternary diagram Na2O-CaO-Al2O3-SiO2-H2O",Cement and Concrete Research, v. 41, n. 9, pp. 923-931, Sep, 2011.

[26] WANG, C. C., "Modelling of the compressive strength development of cement mortar with furnace slag and desulfurization slag from the early strength", Construction and Building Materials, v. 128, pp. 108-117, Dec 15, 2016.

[27] EL-DIN, H. K. S., EISA, A. S. B., et al., "Mechanical performance of high strength concrete made from high volume of Metakaolin and hybrid fibers", Construction and Building Materials, v. 140, pp. 203-209, Jun 1, 2017.

\section{ORCID}

Mehmet Karataş

Murat Dener

Mehrzad Mohabbi

Ahmet Benli https://orcid.org/0000-0002-3705-8463

https://orcid.org/0000-0001-6430-8854

https://orcid.org/0000-0001-8584-1658

https://orcid.org/0000-0002-3005-6123 